\title{
Article
}

http://dx.doi.org/10.11646/phytotaxa.201.2.5

\section{Two new species of Borreria (Spermacoceae, Rubiaceae) from the states of Goiás and Minas Gerais, Brazil}

\author{
LAILA M. MIGUEL ${ }^{1, *}$, ELNATAN B. SOUZA² \& ELSA L. CABRAL ${ }^{1}$ \\ ${ }^{1}$ Instituto de Botánica del Nordeste (UNNE-CONICET), Sargento Cabral 2131, c.c. 209, CP 3400. FACENA-UNNE, Av. Libertad 5460. \\ Corrientes, Argentina. \\ ${ }^{2}$ Universidade Estadual Vale do Acaraú, Av. da Universidade, 850, Betânia, 62040-370, Sobral, Ceará, Brazil. \\ "Author for correspondence: lailammiguel@yahoo.com.ar
}

\begin{abstract}
Two new species of Borreria from Goiás and Minas Gerais are described and illustrated. Borreria minensis was found in "campos rupestres" formation, between 1100 and $1600 \mathrm{~m}$ elevation, and is endemic to Minas Gerais, while Borreria psyllocarpoides was found in the "cerrado" vegetation, at the border of Goiás and Minas Gerais. Electron microphotographs of the seeds and pollen grains, and a distribution map of the two new species are also provided.
\end{abstract}

Key words: Pollen grains, seeds, subsection Borreria, taxonomy

\section{Introduction}

Borreria Meyer (1818: 79) occurs in tropical and subtropical regions of the world, and its, with ca. 100 species, the largest genus of tribe Spermacoceae (Rubiaceae). The generic delimitation of Borreria is controversial. Species in the Paleotropics have all been relegated under synonym of Spermacoce Linnaeus (1753: 102) (Verdcourt 1976, Sivarajan et al. 1987, Dessein 2002, 2003a, Harwood \& Dessein 2005). In the Neotropics, instead, opinions regarding the generic delimitation are divergent. Delprete and collaborators have applied the paleotropical concept of Spermacoce to all Neotropical species in floristic treatments of the genus in specific South American areas (Delprete 2007, 2010; Delprete et al. 2005; Delprete \& Cortés 2006). In contrast, other studies on American species recognized both taxa as separated and maintained Borreria based on inflorescence, pollen, fruit, and seed characters (Bacigalupo \& Cabral 1996, 2007, Bacigalupo et al. 2010, Cabral et al. 2010, 2011, 2012a, 2012b, Miguel \& Cabral 2013, Salas et al. 2011). Additionally, molecular phylogenetic relationship between Borreria and Spermacoce are still unresolved. Molecular work by Kårehed et al. (2008) using chloroplast and nuclear genes weakly supports the concept of relegating Borreria under Spermacoce, but the last one is paraphyletic. Several morphologically well-defined genera are in fact intermingled with Spermacoce species, including i.e. Diodia Linnaeus (1753: 104), Mitracarpus Zuccarini (1827: 210), Richardia Linnaeus (1753: 330) and Psyllocarpus Martius \& Zuccarini (1824: 130). Moreover, this and other currently available studies include few representative species of the Neotropical flora (only nine American species of Borreria in Dessein 2003b; five species in Kårehed et al. 2008; four species in Groeninckx et al. 2009). In all these studies, phylogenetic relationships of American species of Borreria and Spermacoce are unclear. Therefore, because more comprehensive molecular studies and a revision of American species of Borreria and Spermacoce are necessary to disentangle relationships among these two genera, in this paper, we consider both genera as separate, following previous work in our research group (Bacigalupo \& Cabral 1996; Cabral et al. 2011, 2012a, 2012b; Miguel \& Cabral 2013; Salas et al. 2011).

For Brazil, 69 species of Borreria have been recorded, 26 of which occur in the state of Minas Gerais (Cabral \& Salas 2014). The two new species described below are subshrubs characterized by corollas four lobed, exerted stamens and style, bilobed stigma, pantoporate pollen grains, septicidal capsules (dehiscent from the apex) with both cocci dehiscent, and ventrally sulcate seeds. Some of these features also characterize the subsection Borreria (Bacigalupo \& Cabral 1996). Borreria psyllocarpoides is known from both sides of the border between the states of Goiás and Minas 
Gerais, while Borreria minensis is apparently endemic of eastern Minas Gerais. This last species is the third endemic taxon of the state of Minas Gerais together with Borreria rosmarinifolia E. L. Cabral \& Bacigalupo (1997: 48-50) and Borreria valens Standley (1931: 390).

\section{Material and Methods}

Collections and images from the herbaria BHCB, CTES, F, RB, and SI (Thiers 2014) were used in this study and all analyses were based on conventional taxonomic methods. The conservation status for each species was determined following the IUCN (2012) criteria. For descriptions of pollen and seed morphology samples were taken from type specimens. Pollen grains were acetolyzed according to the technique of Erdtman (1952). For light microscopy (LM) analyses, acetolyzed grains were mounted in glycerin jelly. For scanning electron microscopy (SEM) analyses grains were sputter-coated with gold, and examined and photographed using a Jeol $5800 \mathrm{LV}$ SEM at the Universidad Nacional del Nordeste, Corrientes, Argentina. Seeds were examined untreated using the SEM. Pollen terminology follows Punt et al. (2007) and seed terminology follows Stearn (1986).

\section{Taxonomy}

Borreria minensis E. L. Cabral, L. M. Miguel \& E. B. Souza sp. nov. Type:-BRAZIL. Minas Gerais: Serra do Ibitipoca, Pico do Pião, formação rupícola em arenito da série de Lavras, entre 1580-1600 m, 11 May 1970, D. Sucre 6677 (holotype RB!, isotypes CTES!, SI!). (Figs. 1, 3 A-C, 4 A-B).

Borreria minensis is very close to B. tenera Candolle (1830: 543), but differs from that species by its plants many branched from the base ( $v s$. a main stem with few opposite branches), inflorescence with terminal and subterminal glomerules ( $v s$. terminal and numerous axillary glomerules), and stipular sheath with bristles 2-4 mm long (vs. bristles $1-1.5 \mathrm{~mm}$ long).

Erect subshrubs, 6-40 cm tall; main stems 3-15, with numerous side branches, quadrangular, puberulous or with short hairs on the angles, internodes 3-30 mm long. Leaves opposite, with axillary brachyblasts, blades linear, 4$18 \times 0.5-1.5 \mathrm{~mm}$, glabrous, margins revolute. Stipular sheath $1-1.2 \mathrm{~mm}$ long, pubescent to puberulous, edge truncate, with 5-7 bristles; bristles 2-4 mm long, glabrous. Glomerules terminal and subterminal, spherical or subspherical, 4-10 mm diam.; involucral bracts 4-10, linear to narrowly elliptic, $4.3-15.6 \times 0.56-2.08 \mathrm{~mm}$, of the same length or twice as long the glomerule. Flowers sessile; hypanthium $0.9-1.2 \mathrm{~mm}$ long, glabrescent to puberulous; calyx 4-lobed, lobes narrowly triangular, 1.6-1.8 mm long; corolla 4-lobed, infundibuliform, 2.5-2.8 mm long, white, externally glabrous with papillae at the apex of lobes, internally with a ring of moniliform hairs near the middle of the tube; stamens exerted, filaments $0.8-1 \mathrm{~mm}$ long, anthers 1-1.2 mm long; style 3-3.5 mm long, stigma slightly 2-lobed, $0.2 \mathrm{~mm}$ wide, nectariferous disc bipartite. Capsules subglobose, 2.5-2.9 $\times 1.8-2.2 \mathrm{~mm}$, glabrescent to puberulous at the apex. Seeds ellipsoid, $1.2-1.5 \times 0.6-0.8 \mathrm{~mm}$, brown; ventral face with a longitudinal groove covered by the strophiole, raphides located around the strophiole, not showing up clearly on SEM images, hilum on ventral surface, just below the centre of the seed, resembling a small swelling; seed coat surface reticulate-foveate, exotesta cells hexagonal, isodiametrical, microsurface of exotesta cells microperforate, microperforations less than $1.5 \mu \mathrm{m}$ and in the center of the cell.

Pollen morphology:-Pollen grains of B. minensis are spheroidal, 6-7 zonoporate, and 19-21 $\mu \mathrm{m}$ in diam., in polar view the outline is circular. The exine is $3 \mu \mathrm{m}$ thick, the ectopore is $2-2.3 \mu \mathrm{m}$ in diam., the operculum is present; the endoaperture is an indistinct endopore. The tectum is perforated and microspines are uniformly present (Fig. 4 A-B).

Phenology:- - Flowering and fruiting from January to May.

Distribution and Habitat:-Borreria minensis is apparently endemic to Minas Gerais, where it is found in "campos rupestres" between 1100 and 1600 m elevation, in the Serra do Ibitipoca, Serra da Piedade, and Ouro Preto. This area comprises parts of the Mantiqueira Moutains and parts of the Espinhaço Range, including cangas of the Iron Quadrangle (Souza et al. 2012), which have one of the highest levels of endemism (Giulietti et al. 1997). (Fig. 5)

Representative specimens examined (paratypes):-BRAZIL. Minas Gerais: Caeté, Serra da Piedade, campo

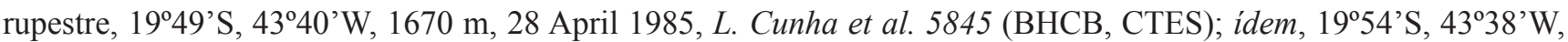
1480-1650 m, 14 May 1990, M. Arbo et al. 4105 (CTES); Ouro Preto, Falcão, campo, 28 January 1942, Mendes Magalhães 1208 (BHCB, CTES). 


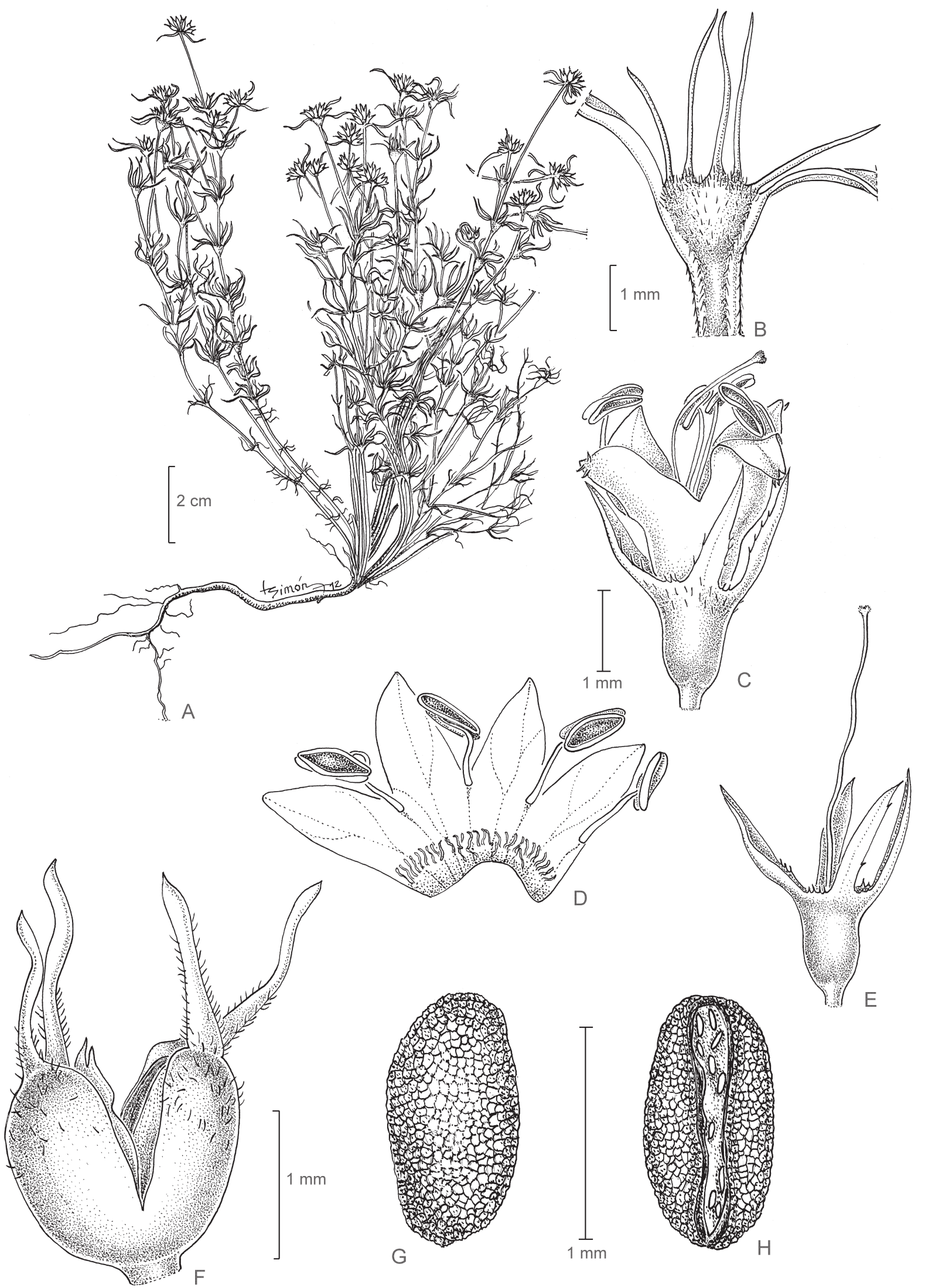

FIGURE 1. Borreria minensis. A. Habit. B. Stipular sheath. C. Flower. D. Corolla, inner view. E. Calyx, style and stigma. F. Fruit. G. Seed, dorsal view. H. Seed, ventral view. 


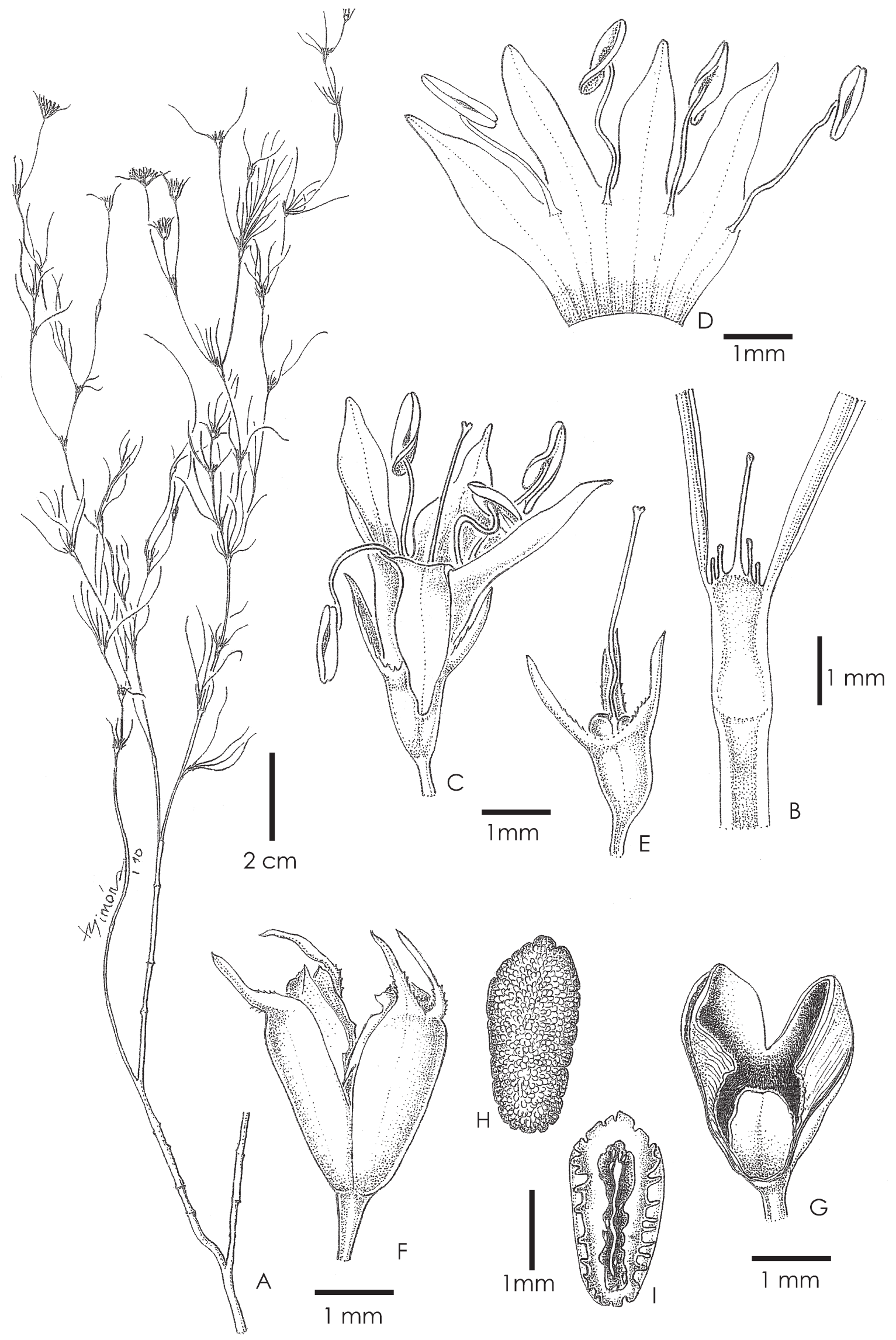

FIGURE 2. Borreria psyllocarpoides. A. Habit. B. Stipular sheath. C. Flower. D. Corolla, inner view. E. Calyx, style and stigma. F. Fruit. G. Dehiscent cocci. H. Seed, dorsal view. I. Seed, ventral view. 
Conservation status:- The species is known from four localities, representing three locations, all outside protected areas. The calculated extent of occurrence is 2,552.106 km². The estimated area of occupancy is $12 \mathrm{~km}^{2}$ (cell size $2 \mathrm{~km}$ ). Therefore, following the IUCN criteria (IUCN 2012), the species should be considered as endangered: EN, B1 a,b(iii) + B2a,b(ii)

Etymology:-The epithet 'minensis' refers to its distribution in the state of Minas Gerais.

Comments:- This species could be confused with B. rosmarinifolia E. L. Cabral \& Bacigalupo, another endemic species from "campos rupestres" between 1100 and 1300 m elevation, in Minas Gerais. However B. rosmarinifolia can be differentiated due to its linear leaves and involucral bracts, which are rigid and oriented towards the apex.

Borreria psyllocarpoides E. L. Cabral \& L. M. Miguel, sp. nov. Type:-BRAZIL. Goiás: Canal de São Simão, 18 September 1972, A. P. Duarte 14082 (holotype RB!, isotypes CTES!, NY, US) (Figs. 2, 3 D-G, 4 C-D).

Borreria psyllocarpoides is similar to B. tenuis Candolle (1830: 543), but differs from that species by the white corolla, glabrous throughout ( $v s$. corolla lilac to pale blue, externally papillose and internally with a fringe of moniliform hairs on the tube and tufts of papillae on the lobes), stamens and style exerted (vs. stamens and style included), pollen grains pantoporate ( $v s$. pollen grains colporate), seeds subellipsoid, $1.5-1.7 \mathrm{~mm}$ long, concave ventral face with a wide longitudinal groove with the margin transversally furrowed, seed coat papillate ( $v s$. seeds obovoid, $0.8-1 \mathrm{~mm}$ long, flat ventral face with a longitudinal groove with entire margin, seed coat reticulate-foveate).
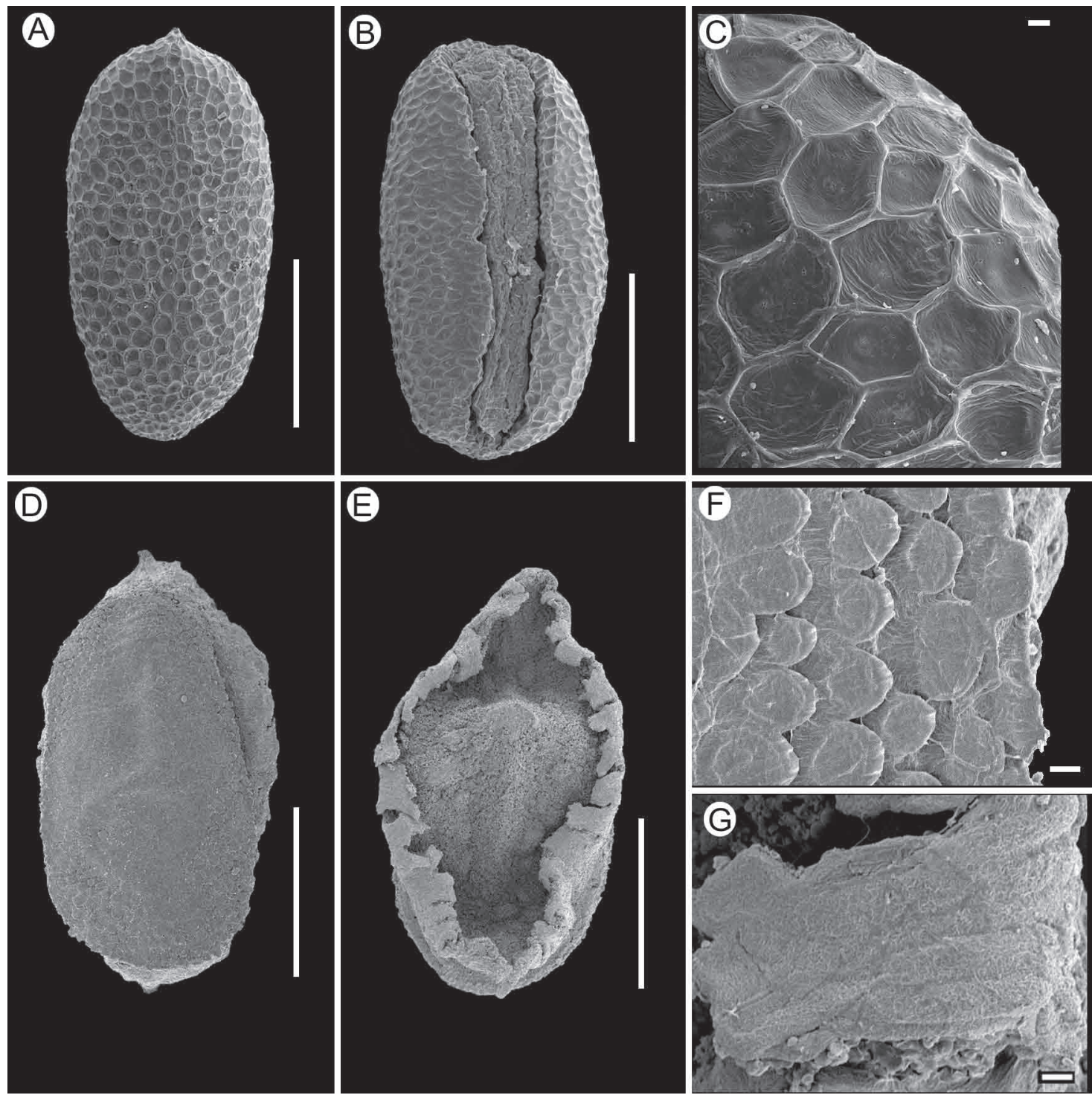

FIGURE 3. Photographs of seeds with SEM. A-C. Borreria minensis. A. Seed, dorsal view. B. Seed, ventral view. C. Detail of the testa surface. D-G. Borreria psyllocarpoides. D. Seed, dorsal view. E. Seed, ventral view. F. Detail of testa surface, dorsal view. G. Detail of testa surface, ventral view. (Scale bars: A, B, D, and E $=500 \mu \mathrm{m} ; \mathrm{C}, \mathrm{F}$, and $\mathrm{G}=10 \mu \mathrm{m}$ ) 

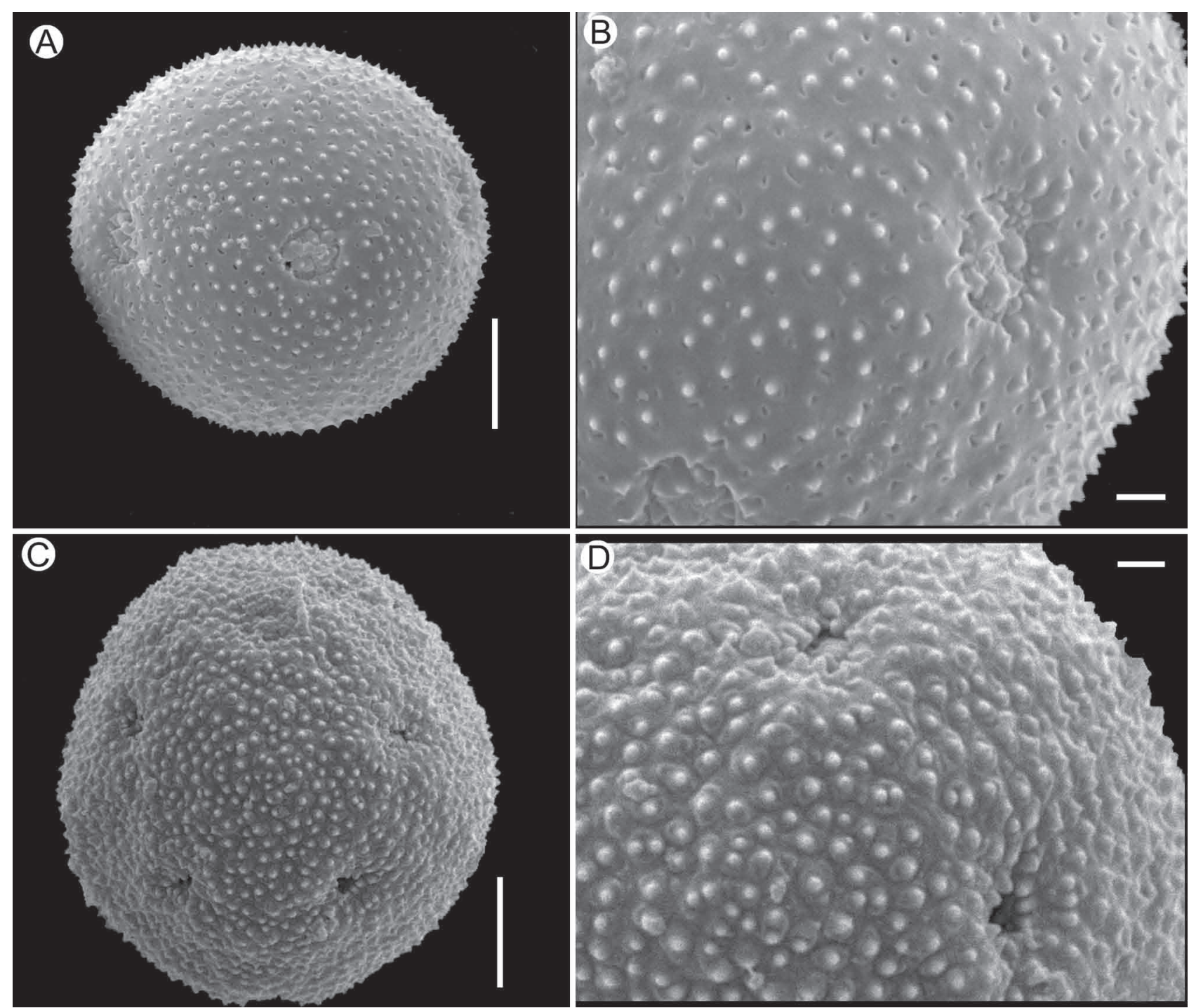

FIGURE 4. Electronical microphotographs of pollen grain. A-B. Borreria minensis. A. Pollen grain. B. Detail of ectoaperture and exine. C-D. Borreria psyllocarpoides. C. Pollen grain. D. Detail of ectoaperture and exine. (Scale bars: A and C = 5 $\mu \mathrm{m}$; B and D $=2 \mu \mathrm{m})$

Erect subshrubs, 36-46 cm tall, distal branches pseudodichotomous; stems quadrangular to terete, glabrous, internodes $0.5-2.5 \mathrm{~cm}$ long. Leaves opposite, pseudoverticillate, with axillary brachyblast, sessile; blades linear, 10-22 $\times 0.2-0.5 \mathrm{~mm}$, glabrous, margins revolute. Stipular sheath 1.8-2 mm long, glabrous, edge truncate with 3-5 bristles; bristles 1-2 mm long, glabrous. Glomerules terminal, pauciflorous, 2-5 mm wide; involucral bracts 2, linear, 4-8 $\times$ $0.2-0.5 \mathrm{~mm}, 2$ times longer than the glomerule. Flowers subsessile, pedicels $0.3-0.5 \mathrm{~mm}$ long; hypanthium 1-1.2 $\mathrm{mm}$ long, glabrous; calyx 4-lobed, lobes narrowly triangular, 1-1.3 mm long, glabrous, margin scaberullous; corolla 4-lobed, infundibuliform, 3.5-3.7 mm long, white, glabrous throughout; stamens exerted, filaments 1.8-2.2 mm long, anthers $1 \mathrm{~mm}$ long; style $3 \mathrm{~mm}$ long, stigma slightly 2-lobed, ca. $0.2 \mathrm{~mm}$ wide; nectariferous disc bipartite. Capsules obovoid, 3-3.3 × 2-2.3 mm, glabrous. Seeds subellipsoid, $1.7 \times 1 \mathrm{~mm}$, brown, ventral side with a wide longitudinal groove, strophiole is not visible in SEM images (probably caducous), seed margin transversally furrowed on ventral side; seed coat papillate, the exotesta cells are isodiametric, with round radial walls, microsurface of the exotesta cells is smooth in dorsal side and rugose in marginal furrow on the ventral side.

Pollen morphology:- The pollen grains of B. psyllocarpoides are spheroidal, 11-12 pantoporate, and 24 (25) 29 $\mu \mathrm{m}$ in diam., in polar view the outline is circular. The exine is $3 \mu \mathrm{m}$ thick, the ectopore is $1 \mu \mathrm{m}$ in diam., the operculum is present; the endoaperture is an indistinct endopore. The tectum is perforate and microspines are uniformly present. (Fig. 4 C-D)

Distribution and Habitat:-Borreria psyllocarpoides occurs in Brazil, in the states of Goiás and Minas Gerais, along the margins of the river Paranaíba, in the Canal do São Simão. This area is included in the "cerrado" vegetation (Fig. 5). 


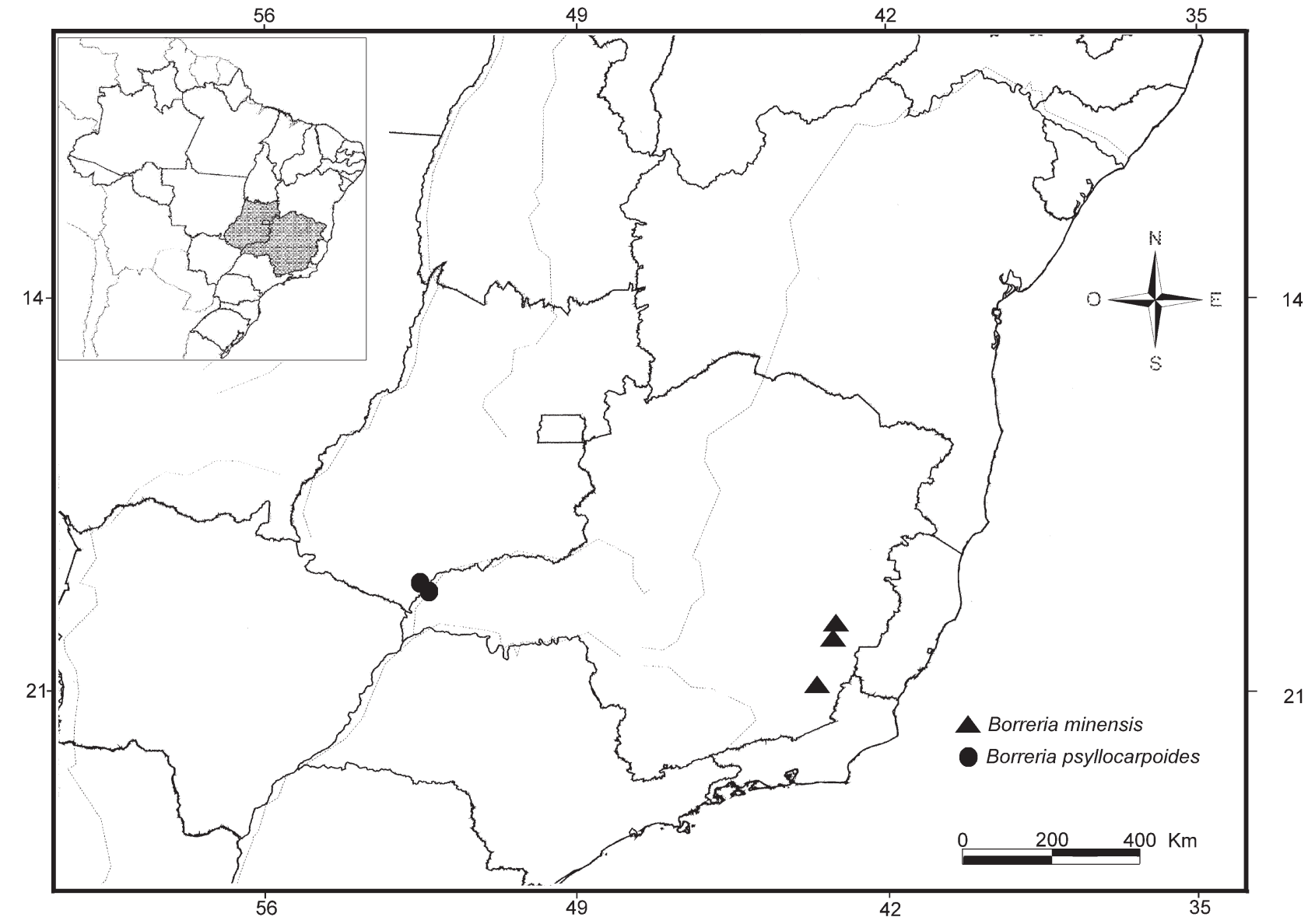

FIGURE 5. Geographic distribution of Borreria minensis and Borreria psyllocarpoides.

Conservation status:- - In this study we analyzed specimens from Canal do São Simão, a narrow canyon of $600 \mathrm{~m}$ wide, formed by the Paranaíba River, and representing the natural limit between the states of Minas Gerais and Goiás. These specimens were collected by Duarte in 1970 and 1972. In 1978, the São Simão Dam began to operate, which meant that the Canal and the original City of São Simão were flooded. Therefore, following the IUCN criteria (IUCN 2012), this species is data deficient (DD) because we consider that information about its current distribution is lacking.

Phenology:- -Flowering and fruiting from September to November.

Etymology:-The specific epithet refers to the similarities of this new species with Psyllocarpus schwackei K. Schumann (1898: 18), another member of the tribe Spermacoceae. Both species are similar in the habits, the linear leaves and the pauciflorous glomerules.

Comments:- Studied specimens were formerly identified as Psyllocarpus in different herbaria and probably the most similar species is Psyllocarpus schwackei which also occurs in Minas Gerais state, in the Serra do Espinhaço (Kirkbride, 1979). However, B. psyllocarpoides differs from P. schwackei mainly by the corolla 3.5-3.7 mm long, white, glabrous throughout, the capsule with septicidal dehiscence from the apex and both cocci dehiscent without a persistent septum, while in $P$. schwackei the corolla is $3.8-6.1 \mathrm{~mm}$ long, blue, externally minutely and densely papillate, internally glabrous, and the capsule dehiscent from the apex downwards along the edge of the septum which is persistent, entire and erect, and both cocci are free.

Representative Specimen Examined (paratype):-BRAZIL. Minas Gerais: Margem do Paranaíba, Canal de São Simão, 2 November 1970, A. P. Duarte 13908 (F, HB).

\section{Acknowledgements}

We thank the two anonymous reviewers for their suggestions on an earlier draft of this manuscript. Also, the first author thanks R. Salas for helping to define the IUCN conservation status of the new species and for valuable comments, and L. Simón for preparing the illustrations. This work is supported by a grant from CONICET. 


\section{References}

Bacigalupo, N.M. \& Cabral, E.L. (1996) Infrageneric classification of Borreria (Rubiaceae-Spermacoceae) on the basis of American species. In: Robbrecht, E., Puff, C. \& Smets, E. (Eds.) 2nd Int. Rubiaceae Conf. Meise (1995). Opera Botanica Belgica 7: 297308.

Bacigalupo, N.M. \& Cabral, E.L. (2007) Tribu Spermacoceae. In: Wanderley, M., Shepherd, G., Melhem, T. \& Giulietti, A.M. (Eds.) Flora Fanerogâmica do Estado de São Paulo 5: 276-285.

Bacigalupo, N.M., Cabral, E.L. \& Cabaña, A.A. (2010) Spermacoce spiralis, a new name for Diodia assurgens (Rubiaceae). Plant Ecology and Evolution 143: 98-102.

http://dx.doi.org/10.5091/plecevo.2010.389

Cabral, E.L. \& Bacigalupo, N.M. (1997) Nuevas especies de la Tribu Spermacoceae (Rubiaceae) para la flora de Brasil. Acta Botânica Brasílica 11: 48-50.

Cabral, E.L. \& Salas, R.M. (2014) Borreria. In: Lista de Espécies da Flora do Brasil. Jardim Botânico do Rio de Janeiro. Available from: http://www.floradobrasil.jbrj.gov.br/jabot/floradobrasil. (accessed 15 October 2014)

Cabral, E.L., Cabaña Fader, A.A. \& Bacigalupo, N.M. (2010) A new species of Spermacoce s. str. (Spermacoceae, Rubiaceae) from Eastern Brazil. Plant Ecology and Evolution 143: 233-238.

Cabral, E.L., Miguel, L.M. \& Salas, R.M. (2011) Dos especies nuevas de Borreria (Rubiaceae), sinopsis y clave de las especies para Bahia, Brasil. Acta Botânica Brasílica 25: 255-276.

http://dx.doi.org/10.1590/S0102-33062011000200002

Cabral, E.L., Miguel, L.M. \& Viana, P.L. (2012a) Two new species of Borreria (Rubiaceae) from Brazil, with new distributional records for Pará State and a key to species with transversally sulcate seeds. Annales Botanici Fennici 49: 209-215. http://dx.doi.org/10.5735/085.049.0310

Cabral, E.L., Miguel, L.M. \& Salas, R.M. (2012b) Comentarios sobre la identidad taxonómica de Borreria valens (Rubiaceae) y descripción de Borreria orientalis, nueva especie de Argentina, Brasil y Paraguay. Boletín de la Sociedad Argentina de Botánica 47:427-434.

Candolle, A.P. de (1830) Spermacoceae. Prodromus 4: 538-578.

Delprete, P. G. (2007) New combinations and new synonymies in the genus Spermacoce (Rubiaceae) for the Flora of Goiás and Tocantins (Brazil) and the Flora of the Guianas. Journal of the Botanical Research Institute of Texas 1: 1023-1030.

Delprete, P.G. (2010) Spermacoce. In: Rizzo, J.Â. (Ed.) Flora dos Estados de Goiás e Tocantins- Coleção Rizzo 40(3): 1153-1309.

Delprete, P.G. \& Cortés, R. (2006) A synopsis of the Rubiaceae of the states of Mato Grosso do Sul, central-western Brazil, with a key to genera, and preliminary species list. Revista de Biología Neotropical 3: 13-96.

Delprete, P.G., Smith, L.B. \& Klein, R.B. (2005) Spermacoce. In: Reis, A. (Ed.) Flora Ilustrada Catarinense, Rubiáceas 2: $702-776$.

Dessein, S. (2002) A new species of Spermacoce (Rubiaceae) from the Manika high plateau (Katanga; R. D. Congo). Nordic Journal of Botany 22: 513-523. http://dx.doi.org/10.1111/j.1756-1051.2002.tb01909.x

Dessein, S. (2003a) Pollen and seeds reveal that Spermacoce thymoidea s. l. (African Rubiaceae, Spermacoceae) represents three endemic or disjunct species from the Zambezian high plateaus. Systematic Botany 28: 130-144.

Dessein, S. (2003b) Systematic studies in the Spermacoceae (Rubiaceae), Ph. D Thesis. Institute of Botany and Microbiology, Laboratory of Plant Systematics, Leuven, 403 pp.

Erdtman, O.G.E. (1952) Pollen Morphology and Plant Taxonomy Angiosperms. Almqvist and Wiksell, Stockholm, 539 pp.

Giulietti, A.M., Pirani, J.R. \& Harley, R.M. (1997) Espinhaço Range Region, Eastern Brazil. In: Davis, S.D., Heywood, V.H., HerreraMacBryde, O., Villa-Lobos, L. \& Hamilton, A.C. (Eds.) Centres of Plant Diversity. A guide and Strategy for their Conservation 3. The Americas. IUCN Publications Unit, Cambridge, 397-404 pp.

Groeninckx, I., Dessein, S., Ochoterena, H., Persson, C., Motley, T. J., Kårehed, J., Bremer, B., Huysmans, S. \& Smets, E. (2009) Phylogeny of the herbaceous tribe Spermacoceae (Rubiaceae) based on plastid DNA data. Annals of the Missouri Botanical Garden 96: 109-132. http://dx.doi.org/10.3417/2006201

Harwood, R. \& Dessein, S. (2005) Australian Spermacoce (Rubiaceae: Spermacoceae). I. Northern Territory. Australian Systematic Botany 18: 297-365. http://dx.doi.org/10.1071/SB03024

IUCN (2012) IUCN Red list categories and criteria. Version 3.1, ed. 2. Prepared by the IUCN species survival commission. IUCN Council. Gland, Switzerland. i-iv +32 pp.

Kårehed, J., Groeninckx, I., Dessein, S., Motley, T.J. \& Bremer, B. (2008) The phylogenetic utility of chloroplast and nuclear DNA markers and the phylogeny of the Rubiaceae tribe Spermacoceae. Molecular Phylogenetics and Evolution 49: 843-866. 
http://dx.doi.org/10.1016/j.ympev.2008.09.025

Kirkbride, J.H.Jr. (1979) Revision of the genus Psyllocarpus (Rubiaceae). Smithsonian Contributions to Botany 41: 1-32.

http://dx.doi.org/10.5479/si.0081024X.41

Linnaeus, C. (1753) Species Plantarum. Laurentius Salvius, Stockholm, 1200 pp.

Martius, C.F.P. \& Zuccarini, J.G. (1824) Psyllocarpus. In: Kunze, G. (Ed.) Ankiindigung der Fortsetzung eines Werkes iiber brasilianische Pflanzen. Flora 7(1): 130-131.

Meyer, G.F.W. (1818) Borreria. Primitiae Florae Essequeboensis adjectis descriptionibus centum circiter stirpium novarum, observationibusque criticis. Sumptibus H. Dieterich, Gottingae, pp. 79-81.

Miguel, L.M. \& Cabral, E.L. (2013) Borreria krapocarmeniana, a new cryptic species recovered through taxonomic analyses of Borreria scabiosoides and Borreria linoides (Spermacoceae, Rubiaceae). Systematic Botany 38: 769-781.

http://dx.doi.org/10.1600/036364413X670368

Punt, W., Hoen, P.P., Blackmore, S., Nilsson, S. \& Le Thomas, A. (2007) Glossary of pollen and spore terminology. Review of Palaeobotany and Palynology 143: 1-81.

http://dx.doi.org/10.1016/j.revpalbo.2006.06.008

Salas, R.M., Soto, D. \& Cabral, E.L. (2011) Dos especies nuevas de Borreria (Rubiaceae), un nuevo registro de Declieuxia y observaciones taxonómicas. Brittonia 63: 286-294.

Schumann, K.M. (1898) Rubiaceae. In: Urban, I. (Ed.) Plantae novae americanae imprimis Glaziovianae. II. Botanische Jahrbücher für Systematik, Pflanzengeschichte und Pflanzengeographie 25: 17-18.

Sivarajan, V.V., Nair Vasudevan, R. \& Ahmed Kunju, T.U. (1987) Genus Spermacoce Linn. (Rubiaceae) in India. Proceedings of the Indian Academy of Science-Plant Sciences 97: 347-358.

Souza, E.B., Cabral, E.L., Marreira, E.M. \& Brandão, E.K.S. (2012) Rubiaceae. In: Jacobi, C.M. \& Carmo, F.F. (Eds.) Diversidade Florística nas Cangas do Quadrilátero Ferrífero. Código Editora, Belo Horizonte, pp. 186-189.

Standley, P.C. (1931) Studies of American Plants-V. Publications of the Field Museum of Natural History, Botanical Series 8: 295-398.

Stearn, W.T. (1986) Botanical Latin. David \& Charles Publishers, London, 557 pp.

Thiers, B. (2014) Index herbariorum. Part I: The herbaria of the world. New York Botanical Garden, New York. Available from: http:// sweetgum.nybg.org/ih/ (accessed 15 October 2014).

Verdcourt, B. (1976) Rubiaceae. Tribe 8. Hedyotideae. In: Polhill, R.M. (Ed.) Flora of Tropical East Africa. Part 1. Crown Agents for Oversea Governments and Administrations, London, pp. 177-315.

Zuccarini, J.G. (1827) Mitracarpus. Mantissa. Vol. 3. Cottae, Stuttgart, 210 pp. 